\title{
Physicochemical composition of some new craft beers consumed in Maroua town from Far North region of Cameroon
}

\author{
M. DIGUIR ${ }^{1}$, A. LAYA ${ }^{2,3},{ }^{,}$, H. WANGSO ${ }^{1}$, J.P. BAYANG ${ }^{2}$, B.B. KOUBALA ${ }^{1,3}$ \\ ${ }^{1}$ Department of Chemistry, Faculty of Science, University of Maroua. P.O. Box 814 Maroua, Cameroon \\ ${ }^{2}$ Department of Biological Sciences, Faculty of Science, University of Maroua. P.O. Box 814 Maroua, Cameroon \\ ${ }^{3}$ Department of Life and Earth Sciences, Higher Teacher's Training College of Maroua, University of Maroua. P.O. Box 55 Maroua, Cameroon \\ `email: laya.alphonse@yahoo.fr
}

Manuscript received: 21 June 2021. Revision accepted: 30 September 2021.

\begin{abstract}
Diguir M, Laya A, Wangso H, Bayang JP, Koubala BB. 2021. Physicochemical composition of some new craft beers consumed in Maroua town from Far North region of Cameroon. Biofarmasi J Nat Prod Biochem 19: 70-80. The work aimed to investigate the physicochemical composition of various craft beers (CB) and their distillates produced in Maroua town. The beers named "Bil-Bil," "Cochette," and "Furdu" were collected both morning and evening time. Dry matter, $\mathrm{pH}$, titratable acid, total dissolved solids, proteins, sugars, carbohydrates, amino acids, and alcohol content were evaluated. The results showed that local beers had a $\mathrm{pH}$ ranging from 4.06 to $4.22,4.15$ to 3.84 , and 3.53 to 3.37 for "Furdu," "Cochette," and "Bil-bil," respectively. The alcohol varied between 5.40 and $6.92 \%$, 1.08 and 5.10\%, 1.73 and 2.88 for "Furdu," "Cochette," and "Bil-bil," respectively. The sugars ranged from 11.85 to $19.05 \mathrm{mg} / \mathrm{mL}$ for "Furdu", from 2.20 to $9.46 \mathrm{mg} / \mathrm{mL}$ for "Cochette" and from 9.92 to $19.78 \mathrm{mg} / \mathrm{mL}$ for "Bil-bil". For amino acids, the values varied from 3.40 to $7.37 \mathrm{mg} / \mathrm{mL}$ for "Furdu", 3.98 to $6.01 \mathrm{mg} / \mathrm{mL}$ for "Cochette" and 2.95 to $3.24 \mathrm{mg} / \mathrm{mL}$ for "Bil-Bil". Regarding protein, the values ranged from 0.80 to $0.85 \mathrm{mg} / \mathrm{mL}$ for these three $\mathrm{CB}$. The distillates of CB collected evening showed high alcohol in fraction 1 . Thus, these CB analyses can be promoted for alternative beer in Maroua town. Furthermore, the unsold CB can be distilled into ethanol.
\end{abstract}

Keywords: Alcohol, craft beers, distillate, Maroua town, physicochemical

\section{INTRODUCTION}

In Africa, cereals are the most widely cultivated and consumed as a staple food in many African households. These cereals are also used to prepare many fermented byproducts. A local transformation unit of these cereals has been found in many areas of Cameroon, the Republic of Central Africa, and Chad (Djanan et al. 2002). The enterprises are mostly performed by women who recruit at least three workers (Maoura et al. 2002). In Cameroon, especially in the Northern part of Cameroon, various cereals such as sorghum, maize, yellow millet, S35, rice, and fonio are processed into alcoholic and non-alcoholic beverages called beer or ancestor drink locally. These local beers produced are well appreciated by numerous people of Cameroon and other countries because they are a good source of nutrients such as amino acids, carbohydrates, vitamins, minerals, phenolics, etc. (Maoura et al. 1999; Bamforth 2002; Lyumugabe et al. 2012; Cirimina et al. 2018). Because of their probiotics, these local beers as known as therapeutic agents. The local beer is a beverage of significant historical and cultural importance. It is gaining the popularity of craft beer and is of growing interest in several countries. It is also providing alternatives to mainstream beer production (Einfalt 2021). To date, craft beer is one of the fastest-growing alcoholic beverage industries throughout the world (Gómez-Corona et al., 2016).

These local beers are known as Bil-Bil Furdu and Cochette, the most widely produced and consumed.
According to the tribes, these beers have different names, "Bil-Bil" beer is known as "Muzum" in Guiziga; "Ouzomm" in Mada, "Zoum" in Mafa; "Balda" in Guidar; "Himi" in Moudang; "Yii" in Toupouri; "Tcheu" in Kapsiki "Mbolo" in Fali; "Mgba" in Laka; "Amgba" in Baya; "Do'di" in Dourou and "Coumouille" in Kera. However, "Furdu" beer is known as "Bazdltah" in Mada, "Pram" or "Bazla Babara" in Guiziga, "Mpedli" in Kapsiki. The "Cochette" beer is known as "Cochette" in almost all tribes but differs by pronunciation except the name in the Mada tribe, "Mohosso." The local name of Bil-Bil vary from one country to another as Bili-Bili in Cameroon and Chad, Dolo in Burkina-Faso, Mali and Senegal; Tchapalo in Ivory Coast, Tchoukoutou in Benin, Pito in Ghana, and Impéké in Burundi (Odunfa 1985; N'da et al. 1996; Kayodé et al. 2005). At the same time, Furdu and Cochette are new local beers that are not documented in the literature. The energy is provided at $70 \%$ by alcohol and $30 \%$ by carbohydrates (Lariven and Rigal 2017). According to Djanan et al. (2002), one liter of Bil-Bil contributes significantly to the recovery of iron, magnesium, manganese, phosphorus, and calcium dietary allowance per day for an adult. Various studies of Bil-Bil beer are investigated. However, these parameters are absent for Furdu and Cochette beers. Setta et al. (2020) reported that traditional African fermented cereal-based beverages are potential probiotic carriers because of the probiotic Lactobacillus spp. and yeasts involved in the fermentation of such products. They can be used as probiotic health benefits for most African populations. 
The main concern of all the local beers is their consumption for one to two days, and the next day, these beers become more acidic due to the breakdown of ethanol into acetic acid (oxidation reactions). Finally, unsold local beers are usually thrown. These unsold beers can be used in the production of quality by-products in order to have added value and solve the pollution problem.

Thus, the present study aimed to determine the physicochemical composition and distilled some craft beers named Bil-Bil, Furdu, and Cochette in order to valorize the local beers mostly consumed in Maroua town of Cameroon.

\section{MATERIALS AND METHODS}

\section{Survey}

The survey was conducted in order to find out more about the micro-enterprises in charge of the production of local beer in the town of Maroua, the region of the Far North of Cameroon. A preliminary survey was carried out in all streets of Maroua. We identified four streets where they produced mostly local beers: Pitoare, Pont-vert, Ourotchede, and Palar. During this survey, several local beers are consumed in the town of Maroua. However, based on the most consumed in the city, we have identified three (03) types of local beers: Furdu, Cochette, and Bil-Bil. After this first step, we conducted a survey using direct interviews with the producers and consumers of these beers. We interviewed 150 producers and 200 consumers of Bil-Bil beer, 20 producers and 35 consumers of Frudu beer, and 20 producers and 40 consumers of Cochette beer.

\section{Samples}

Samples of Cochette, Furdu, and Bil-Bil beers were purchased through the various producers located on four streets (Pitoare, Pont-vert, Ouro-tchede, and Palar). The samples were collected in the morning (start of the sale) and the evening (end of the sale) from the suppliers and were introduced in a suitable and sterile container and then labeled (Figure 1). Samples were transported to the Biochemistry Laboratory and Biological Chemistry of the University of Maroua (LabBBC). All samples were kept at$10^{\circ} \mathrm{C}$ before Physico-chemical analyses and distillation.

\section{Processing flow charity of different beers preparation}

The craft beers were produced using different cereals shown in Figure 2.

Shortly, the cereal was soaked for $24 \mathrm{~h}$ and washed before germination (2-3days). The germinated cereal was sun-dried before milling, the malt flour was mixed with water, and the mash mixture was decanted for $30 \mathrm{~min}$. The supernatant was heated for $2-3 \mathrm{hr}$ and allowed to rest overnight. Then, the second heating was done for 2-4 to obtain the sweet wort, which was cooled for $3 \mathrm{hr}$ or more. Finally, the wet yeast was added and fermented overnight to obtain bil-bil beer. Figure 2.A shows the Bil-Bil beer preparation.

In brief, $7.0 \mathrm{~kg}$ of cereal was soaked for 1-2 days before sundering for $3 \mathrm{hrs}$ and milling in order to obtain flour (malt). Then, mixed with water before boiling at $95^{\circ} \mathrm{C}$, the mash obtained was cooled at room temperature for $3 \mathrm{hr}$ before adding the wet yeast. The mixture was fermented for 10-12hrs and then filtered throughout the traditional filter tissue. The filtrate was poured into a jar and named Cochette beer. Figure 2.B shows different steps to produce Cochette beer.

Briefly, 3-7kg of cereal was wetted, cleaned, or watered and germinated for three days and sun-dried before milling, and the malt flour obtained was mixed with water, heated $\left(95^{\circ} \mathrm{C}\right)$, and the mash obtained was cooled at room temperature for $4 \mathrm{hr}$. Then, the mash was fermented for $72-$ $100 \mathrm{hr}$ and filtered throughout the traditional filter mesh. The product obtained was poured into a jar, and the fur beer was ready for drinking. Figure 2.C shows the summary methodology to produce Frudu beer.

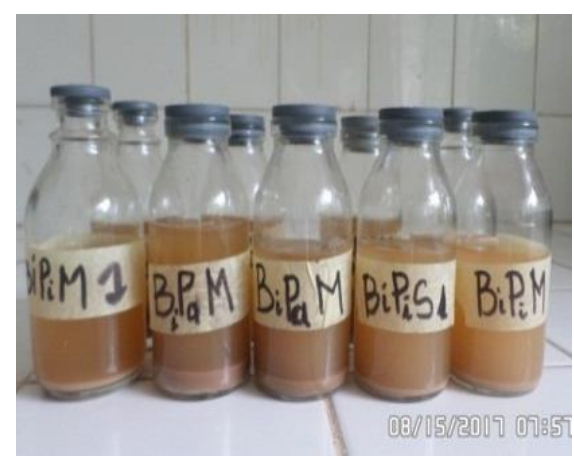

A
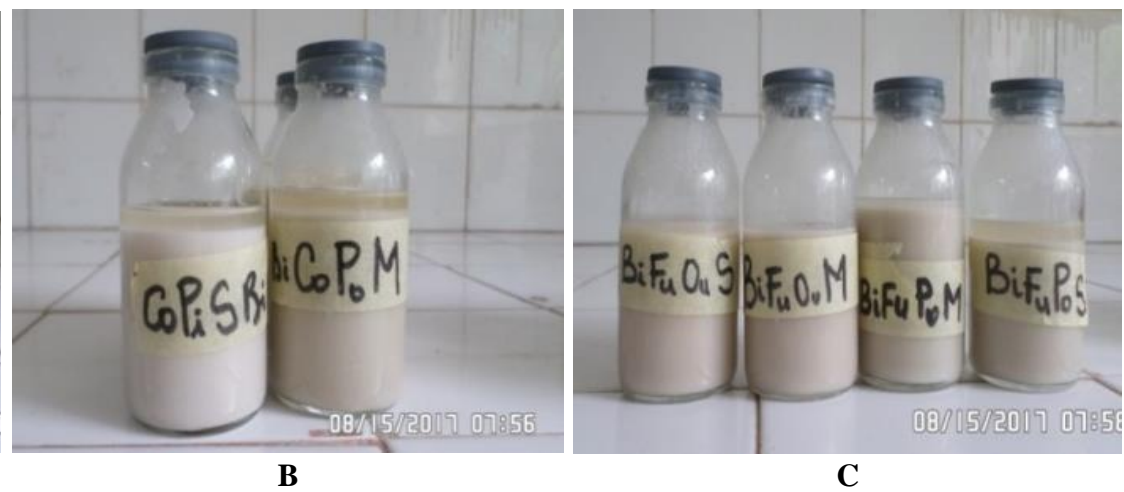

Figure 1. Sample of different craft beers mostly produced and consumed in Maroua town, Cameroon. A. Bil-bil Beer, B. Cochette Beer, C. Furdu Beer 


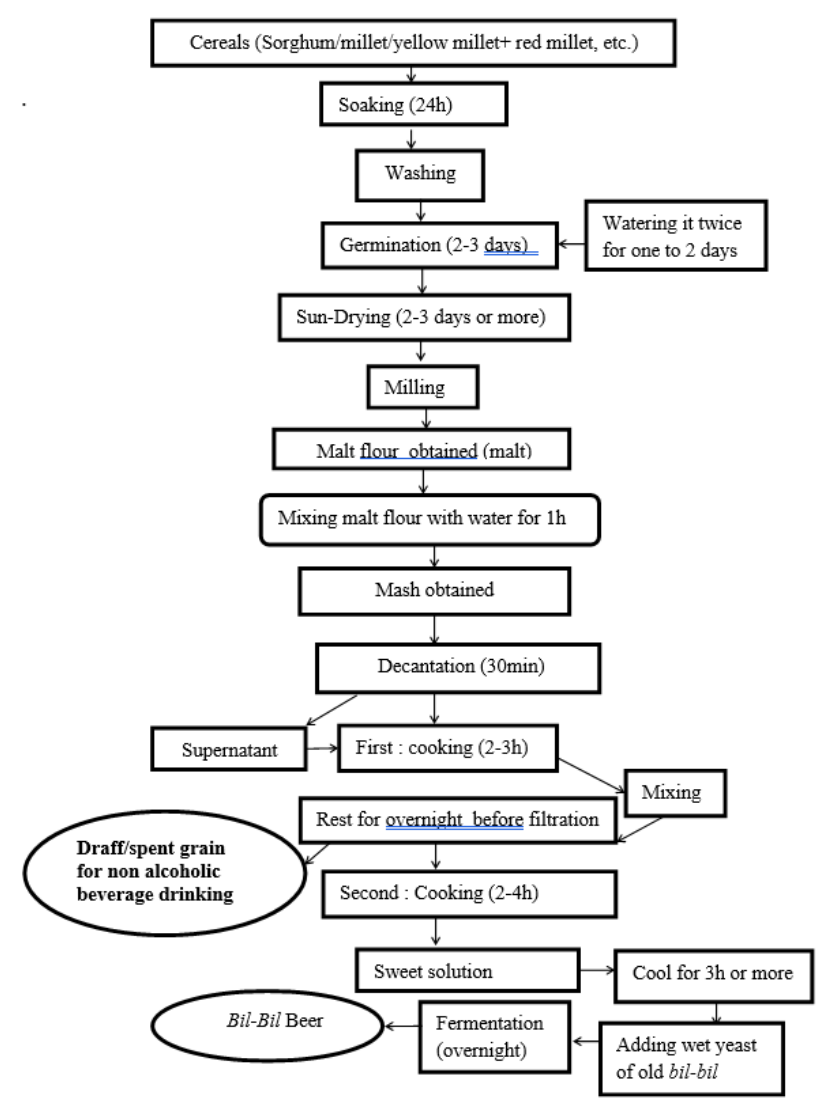

\section{A. Bil-bil beer}

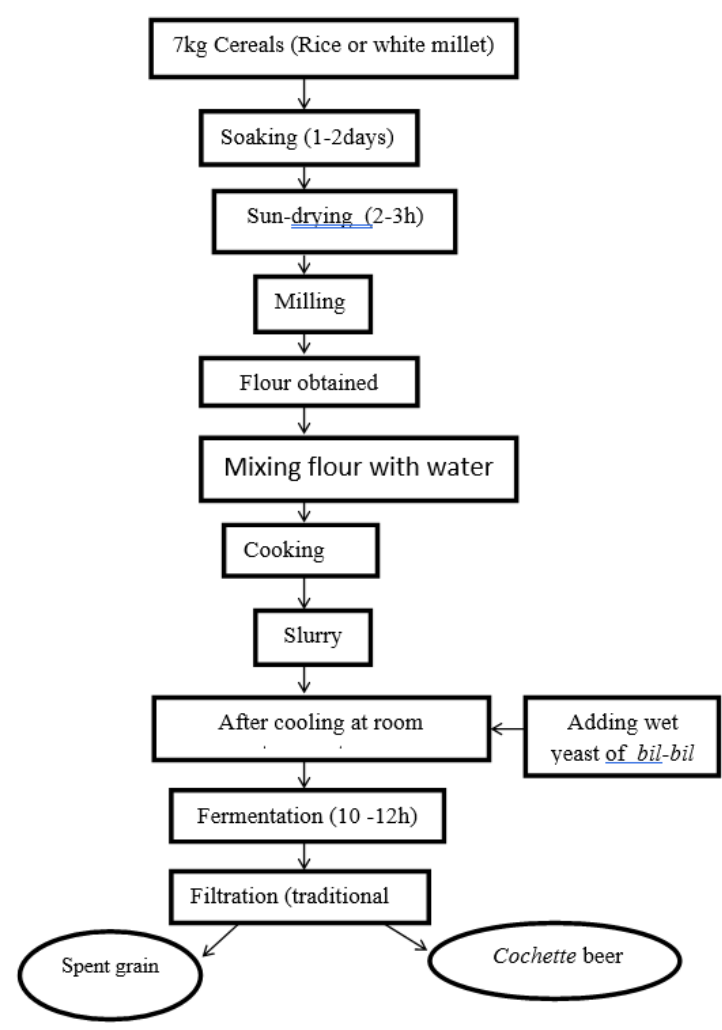

B. Cochette beer

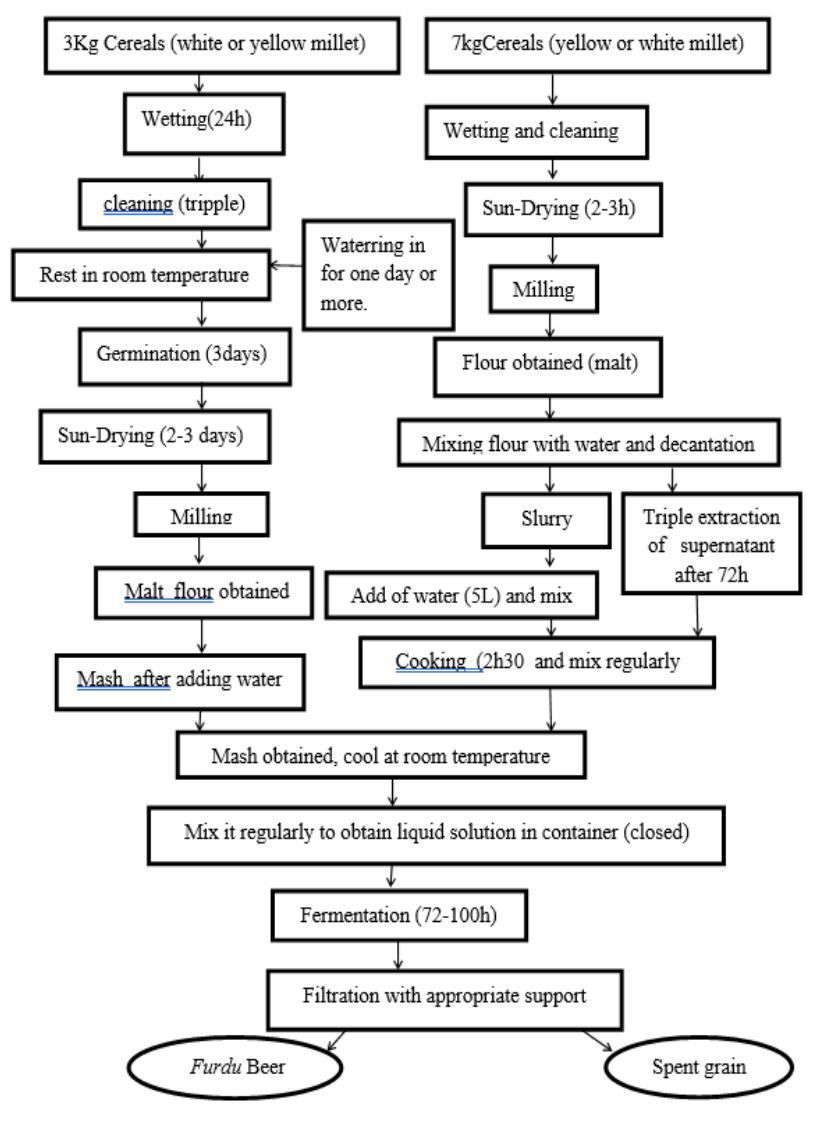

C. Frudu beer

Figure 2. Flow charity preparation of beers in Maroua, Cameroon. A. Bil-bil Beer, B. Cochette Beer, C. Furdu Beer

\section{Reagents and chemicals}

Bovine Serum Albumin (BSA), Ninhydrin, Alanine, glucose, and 3,5-Dinitrosalicyclic Acid (DNSA). Sulfuric acid, Ethanol, Chloridric acid, Acetic acid, Nitrochromicacid, Iodic of potassium blue of coomassie, Sodium of thiosulfate, and all other solvents were obtained from Sigma-Aldrich (Iowa, USA) and Fisher commercial source (New Jersey, USA).

\section{Kinetics of distillation}

A beer sample was collected in the morning and evening from different streets (Pitoare, Pont vert, Ouro tchede, and Palar) of Maroua town. The kinetics of distillation was evaluated as affected by the time and temperature. $400 \mathrm{~mL}$ of sample was introduced in $500 \mathrm{~mL}$ rotavapor flash and was allowed to heat until boiling. In the end, two fractions of distillates were collected for analysis.

\section{Physicochemical analyses}

Total dissolved solids (TDS), Dry matter content (DM), $p H$

TDS was determined in triplicate using the TDS instrument, and the values were expressed in ppm. However, dry matter content and $\mathrm{pH}$ were evaluated as described by AOAC (2000) method. 


\section{Titratable acidity}

Titratable acidity was determined as described by Ranganna (1979). The values were expressed in milligram equivalent oxalic acid per 100 grams of sample beer.

\section{Evaluation of reducing sugars content}

Reducing sugar content was determined using the dinitrosalicylic acid as described by Miller (1972). The results were expressed in $\mathrm{mg}$ per $\mathrm{mL}$ of sample beer.

\section{Evaluation of total carbohydrates content}

Total carbohydrate content was determined as described by Dubois et al. (1956). The results were expressed in mg per $\mathrm{mL}$ of sample beer.

\section{Determination of total amino acids, proteins, and alcohol content}

Total amino acids content was determined using ninhydrin (1\%) reagent as described by Michel and Hannequart (1968). The results were expressed in $\mathrm{mg}$ of amino acids per $\mathrm{mL}$ of sample beer.

Total soluble protein content was determined using Bradford's (1976) method. The results were expressed in $\mathrm{mg}$ of BSA per $\mathrm{mL}$ of beer sample.

The content of alcohol in sample beer was determined as described by Caputi et al. (1968).

\section{Statistical analyses}

SPSS 20.0 Statistical Package for Windows (SPSS Inc., Chicago, IL, USA) was used to perform all statistical analyses. Experiments were done in triplicate, and one-way analysis of variance (ANOVA) was performed. Tukey's (HSD) test was used to determine any significant difference between different beers, and the significance level was accepted at $\mathrm{p}<0.05$. The results were expressed as means \pm standard deviation.

\section{RESULTS AND DISCUSSION}

\section{Sociodemographic profile of producers and consumers of local beers}

The survey results revealed that women between 20 and 40 represent most brewers (Table 1). They are predominantly catholic Christians, followed by Protestants and a few animists for all beers. Most women are married ( $\geq 60 \%$ ), followed by widowed, single, or divorced. Their education level varies from primary to secondary school, and they are illiterate as well (Table 1). In Moundou, Tchad, similar results were reported by Djitod (2002) on Bil-bil beer, who found that most producers are catholic Christians (87\%), aged between 26 and 35 years. Also, they are married women (65\%), divorced (15\%), widows (13\%), and single $(7 \%)$. The producers of local beers in Maroua town, mainly women, suggested that men are only the consumers, consistent with Cameroon's Northern tradition.

Results also showed that the youngest people aged between 20 and 40 (75\%) mainly consume Bil-Bil beer
(Table 1). Also, it found that furdu is more consumed by Protestants $(57.7 \%)$ than others. However, Bil-bil $(52 \%)$ and Cochette $(50 \%)$ are mostly consumed by catholic Christian (Table 1). Then, other Christians such as Pentecostist, Adventists, Presbyterians, and Muslims have consumed all types of beers. The consumers are predominantly married $(\geq 50 \%$ ) for all the beers than widowed, single, and divorced. They have a level of education, mostly between secondary and higher education, and a few proportions of primary and illiterate (Table 1).

Furdu and Cochette beers are mostly consumed by people with a primary level of education. Pupils (32\%) and students $(27.5 \%)$ are consumers of Bil-Bil beer. Furdu and Cochette are mostly consumed by the elder person aged between 40 and 60 , with a percentage of $63 \%$ and $45 \%$, respectively, followed by the youngest people aged between 20 and 39 years (Table 1). Also, according to our survey, low-income men and married people, unemployed and rich people have consumed the local beers in different streets of Maroua town every day from the morning (5 a.m.) to the evening ( 8 p.m.). The consumption of these craft beers may be due to their traditional value, interest in the tasting (Einfalt 2021), therapeutic value, and lower cost than commercial beers (modern beer). In fact, certain untypical flavors in craft beers even have the potential of being perceived by the consumer as having higher quality than commercial beer (Ascher 2012).

\section{Different cereals are used for the production of local beers in Maroua town}

The survey revealed that various cereals are used to produce local beers (Bil-Bil, Furdu, and Cochette) in Maroua town. Cereals mostly used are maize, rice, fonio, and sorghum. Rice and white sorghum were the main cereal for Cochette (40\%), and for Furdu beer, it was white sorghum (85\%) (Figure 3). While, Bil-Bil was the mixture of all of these different cereals. The mixture of red and yellow sorghum (46\%) followed by red and white sorghum $(38 \%)$, red sorghum, S35, and red-yellow sorghum and $\mathrm{S}_{35}$ were the most used by Bil-Bil producers, respectively (Figure 3). The present results are consistent with the results found by Charles et al. (2018), who reported that in North Cameroon, red sorghum ("djagari") was the main cereal for the production of Bil-Bil beer. The results of the survey regarding producers show that Bil-Bil beer, produced with a mixture of red sorghum, exhibited better drinking. However, beer of red sorghum was absent in Maroua town, while yellow and withe sorghum was the best cereal for the production of Bil-Bil beer (Figure 3).

Therefore, many factors can affect the quality of these local beers, such as the quality of heat during preparation $(33 \%)$, type and germination of grain $(18 \%)$, and other factors (Figure 4). These are consistent with the results reported by Olaniran et al. (2017). They stated that the quality of the final product (beer) is influenced by several variables, such as the quality of the raw material, type of malting, the applied preparation method of the wort, type of hops, type and quality of yeast, fermentation time, maturation, and pasteurization and filtration, among others. Table 1. Results of survey (\%) of the local beers collected from consumers and producers from the different streets of Maroua town. Values are rated answers concerning the consumption or production of Bil-Bil, Cochette, or Furdu beers. 


\begin{tabular}{|c|c|c|c|c|c|c|c|}
\hline Parameter & & $\begin{array}{l}\text { Bil-Bil } \\
\text { Consumers }\end{array}$ & Producers & $\begin{array}{l}\text { Cochette } \\
\text { Consumers }\end{array}$ & Producers & $\begin{array}{l}\text { Furdu } \\
\text { Consumers }\end{array}$ & Producers \\
\hline \multirow[t]{4}{*}{ School-level } & Primary & 22.5 & 39 & 50 & 60 & 57.1 & 50 \\
\hline & Secondary & 32 & 41 & 20 & 20 & 22.9 & 20 \\
\hline & Higher & 27.5 & 0 & 12.5 & 0 & 10 & 0 \\
\hline & Illiterate & 10 & 20 & 17.5 & 20 & 10 & 30 \\
\hline \multirow{4}{*}{$\begin{array}{l}\text { Matrimonial } \\
\text { status }\end{array}$} & Married & 50 & 63 & 60 & 75 & 69 & 50 \\
\hline & Single & 40 & 14 & 10 & 15 & 11 & 20 \\
\hline & Widow & 4 & 20 & 17.5 & 10 & 20 & 30 \\
\hline & Divorced & 6 & 3 & 12.5 & 0 & 0 & 0 \\
\hline \multirow[t]{7}{*}{ Religion } & Animist & 4 & 7 & 12.5 & 15 & 22.9 & 20 \\
\hline & Protestant & 33 & 13 & 30 & 5 & 57.1 & 0 \\
\hline & Presbyterian & 1.5 & 0 & 0 & 0 & 0 & 0 \\
\hline & Muslim & 3 & 0 & 0 & 0 & 0 & 0 \\
\hline & Pentecost & 6.5 & 0 & 0 & 0 & 0 & 0 \\
\hline & Catholic & 52 & 80 & 50 & 80 & 20 & 80 \\
\hline & Adventist & 0 & 0 & 7.5 & 0 & 22.9 & 0 \\
\hline \multirow[t]{3}{*}{ Age } & {$[0-20[$} & 10 & 3 & 20 & 5 & 8.5 & 10 \\
\hline & [20-40[ & 75 & 77 & 35 & 50 & 28.5 & 60 \\
\hline & [40-60[ & 15 & 20 & 45 & 45 & 63 & 30 \\
\hline
\end{tabular}

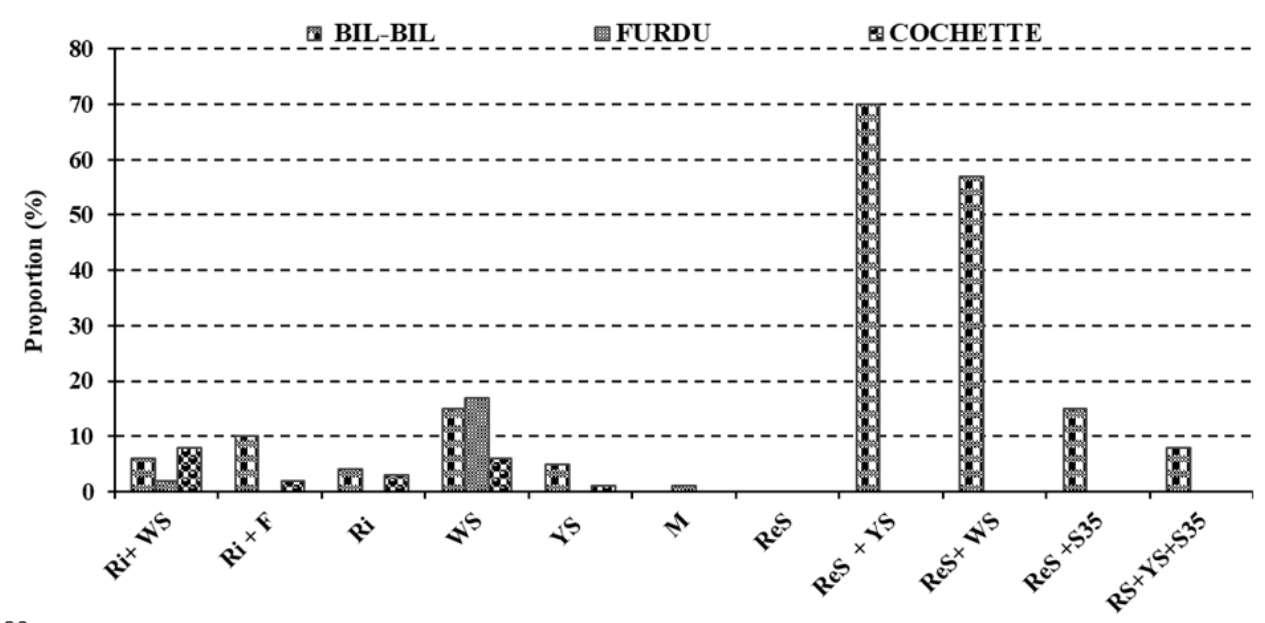

Figure 3. Proportion of the various combination of cereals used according to producers for craft brewery. Ri + WS $=$ Rice + White Sorghum $; \mathrm{Ri}+\mathrm{F}=$ Rice + Fonio $; \mathrm{Ri}=$ Rice, $\mathrm{WS}=$ White Sorghum, YS = Yellow Sorghum $; \mathrm{M}=$ Maize $; \mathrm{RS}=$ Red Sorghum $; \mathrm{RS}+\mathrm{YS}=$ Red Sorghum + Yellow Sorghum ; ReS + WS = Red Sorghum + White Sorghum ReS+YS+S35 = Red Sorghum + Yellow Sorghum + S35.

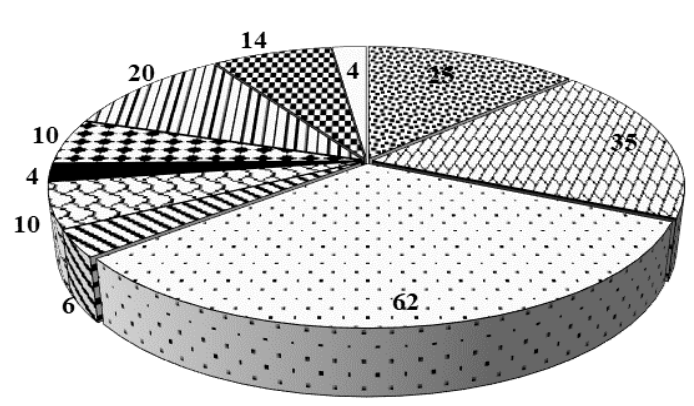

GCooking

GGermination

GExtreme heat

$\checkmark$ Lack of experience

cCer eal cleaning

cooling

⿴囗十 Yeast

৫Quality of cer eal

DMeasures

口Use of pesticides

Figure 4. Factors influencing the craft brewery. 
The influence of time and temperature on the volume of distillate

Figure 5.A-B shows the evolution of distillation of beers collected both morning and evening. The curve (Figure 5.A) showed many stages during the distillation. The curve showed that all craft beers had a significant amount of alcohol at the start time. According to Anderson (2012), in a binary, tertiary, or quaternary non-azeotropic mixture, the most volatile constituents are those whose boiling point is the lowest at constant pressure, which qualified as light at $1 \mathrm{~atm}$, and the least volatile constituent is the one with the highest boiling temperature at constant pressure qualified as heavy at $1 \mathrm{~atm}$. From the point of boiling temperature of methanol $\left(64^{\circ} \mathrm{C}\right)$, ethanol $\left(78^{\circ} \mathrm{C}\right)$, propana-2-ol $\left(82^{\circ} \mathrm{C}\right)$, propana-1-ol $\left(97^{\circ} \mathrm{C}\right)$ of water $\left(100^{\circ} \mathrm{C}\right)$, and other products resulting from oxidation such as acetone $\left(56^{\circ} \mathrm{C}\right)$. Samples CPiM, BPaM, CPvM, FHoM, and $\mathrm{BPvM}$ for those collected in the morning (Figure 4.A) and $\mathrm{BPvE}, \mathrm{FHoE}, \mathrm{CPvE}$, and $\mathrm{BPaE}$ for those in the evening (Figure 5.B) and especially at different time intervals lets us believe in their presence. Other samples FPvM $\left(71^{\circ} \mathrm{C}\right)$ and $\mathrm{BPiM}\left(72^{\circ} \mathrm{C}\right)$ for those from the morning and $\mathrm{FPvE}$ $\left(75^{\circ} \mathrm{C}\right)$ and $\mathrm{BPiE}\left(73^{\circ} \mathrm{C}\right)$ for those from the evening and their distillation time at a value of maximum boiling temperature strictly lower than that of ethanol is what also leads us to believe in an abundance of methanol, acetone, and others.

These differences are due to the raw materials used, the brewing methodology, and the time and period of inoculation of the yeasts to obtain a perfect fermentation of alcohol. Fact, at temperature values strictly below and above the boiling point of ethanol, there is no more ethanol to distillate in the local beer but many alcohols and other mixed products. Higher alcohols (2-methyl-1-propanol, 2methyl-1-butanol, and 3-methyl-1-butanol) derived from the catabolism of amino acids and sugars via the Ehrlich pathway are common in fermented and distilled beverages (Hazelwood et al. 2008; Nascimento et al. 2008). Gas chromatography (GC-FID) and GC-MS method for the detection and quantification of these different alcohols and other compounds in the mixture has not been carried out in the present study, so we believe many other compounds may be present. Recent works show many volatile compounds, namely aldehydes, esters, alcohols, and acids, have been identified by using different chromatography methods in cassava spirit and traditional sorghum beer (Attchelouwa et al., 2020; Coelho et al., 2020), which derived from the fermentative metabolism of yeast and can be further concentrated during the distillation.

Figure 5.C-D shows the evolution of the volume of the distillate of various beers collected at different times (morning and evening). We noticed that the increase in volume at different times and temperatures varied concerning the types of beers. All samples of beers from the morning to the evening had maximum boiling temperature with values greater than or equal to $78^{\circ} \mathrm{C}$ ( $\mathrm{T}$ $\geq 78^{\circ} \mathrm{C}$ ) and showed the highest value in terms of volume, $15.9 \mathrm{~mL}$ (BPvM), $15.8 \mathrm{~mL}$ (CPiE) for low value and $20.85 \mathrm{~mL}$ (CPiM), 21.3mL (BPvE) for high values. Almost ethanol content of sample beer was collected in different fractions, with distillation efficiency close to $100 \%$ (Coelho et al. 2020). On the other hand, we did not collect all the ethanol found in some samples whose boiling point was strictly below $78^{\circ} \mathrm{C}$. We think it might take longer than we defined, or at least there was not enough ethanol but other alcohols in those initial samples of beers.

Therefore, we obtained the smallest values in terms of volume with the value of $13.65 \mathrm{~mL}(\mathrm{BPiM})$ and $15.8 \mathrm{~mL}$ (FPvM) for the morning sample (Figure 4.C) and $15.8 \mathrm{~mL}$ (CPiE), $16.84 \mathrm{~mL}(\mathrm{BPiE})$ and $18.55 \mathrm{~mL}(\mathrm{FPvE})$ for those of the evening (Figure 4.D).

In general, the volume of distillate from the evening was significantly greater than in the morning. This variation in volume between the samples collected in the morning and those from the evening may be due to the influence of the brewing technology, the raw material used (Humia et al. 2019), and the quality of yeast (Einfalt 2021) as well as the time of maturation which affect the fermentation of the different beers. This difference proves sufficiently that regardless of the temperature values greater than or equal to, less than, or equal to the boiling temperature of ethanol $50 \leq \mathrm{Tb} \leq 90$, we do not only collect ethanol and other alcohols mixed but also a significant amount of water. In short, at a high temperature of around $100{ }^{\circ} \mathrm{C}$, the distillate to be recovered consists of maximum water and very low alcohol content.

\section{Variation of some physicochemical characteristics in local beers}

The physicochemical characteristics of Bil-bil, Furdu, and Cochette are shown in Table 2. Statistical analysis showed a significant $(\mathrm{p}<0.05)$ difference among samples (Table 2). The results showed that the TDS of all the investigated beers vary. However, Furdu beer has the highest TDS value (1688-1978 ppm), while the lowest was shown by Cochette (513-1409 ppm). The present results agree with Coulibaly et al. (2020). They found in traditional sorghum beer (Tchapalo) in the Ivory Coast a value of $15.60{ }^{\circ} \mathrm{B}$, which was more variable than our values. This difference must be linked to the methodology and the cereal type to produce local beer. While dry matter content of the beers varied between 4.24 to $6.98 \%$ (Bil-Bil), 2.83 to $6.96 \%$ (Furdu), and 5.17 to $8.06 \%$ (Cochette). Compared to the result obtained by Amane et al. (2005), the local beers investigated had a similar dry matter (7.87 $\%)$ to Sorghum Tchapalo produced on Ivory Coast. Chevauss-Agnes et al. (1976) also obtained similar results, finding that Ambga beer had $7.2 \%$ dry matter. These differences may be due to production practices and the variety of cereals used in processing these beers. 


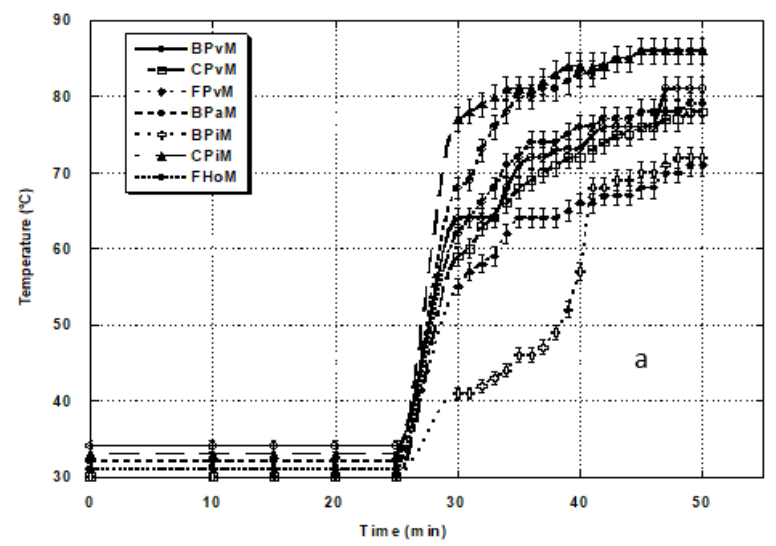

A

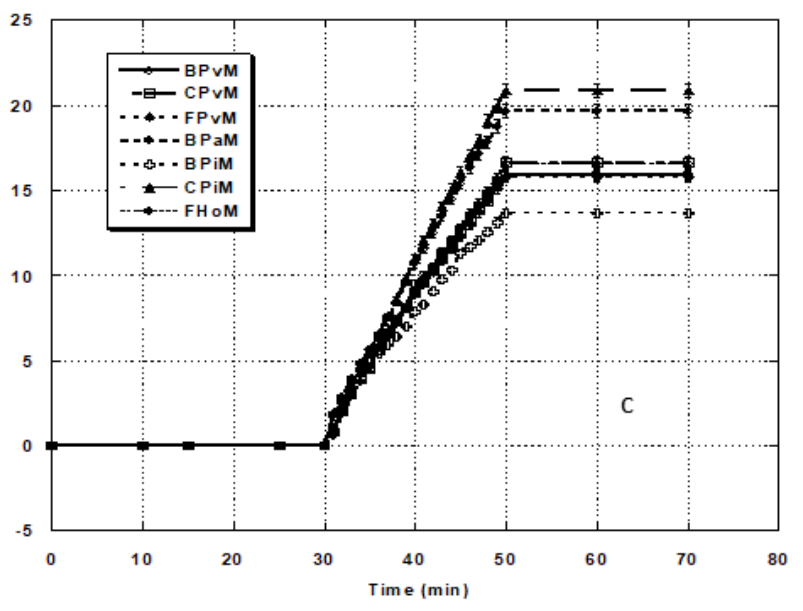

C

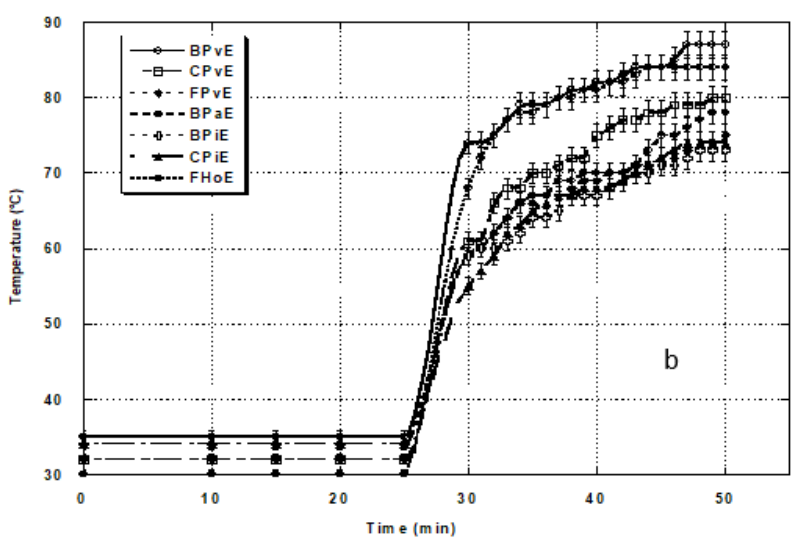

B

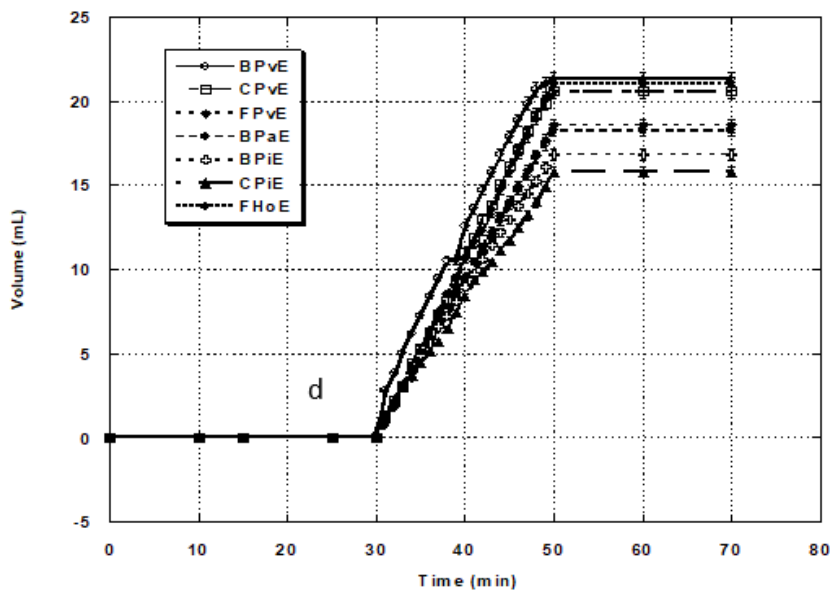

D

Figure 5. The distillation temperature and volume are according to the time of the local beers collected. A-B. Evolution of the distillation temperature according to the time of local beers collected (A. collected morning, B. collected evening). C-D. Increase distillate volume according to the time of the local beers collected (C. collected morning, D. collected evening). Note: FHo: Furdu beer collected in Ouro tchédé street; FPv: Furdu beer collected in Pont vert street, CPv: Cochette beer collected in Pont vert street, CPi: Cochette beer collected in Pitoaré street, BPv: Bil-Bil beer collected in Pont vert street, BPa: Bil-Bil beer collected in Palar-street, BPi: Bil-Bil beer collected in Pitoaré street. Those beers were collected in the evening (E).

The $\mathrm{pH}$ value of different beers varied, as shown in Table 2. It varied from 3.53 to 3.37 (Bil-Bil), 3.84 to 4.15 for "Cochette," and 4.06 to 4.22 for furdu beer. Compared to the values obtained by Roger et al. (2013) in Amgba beer ( $\mathrm{pH} 2.5)$, Tchapalo $(\mathrm{pH} 3.4)$ by Aka et al. (2008), Dolo (pH 3.5) by Abdoul-latif et al. (2013), Pito (pH 3.66) by Fadahunsi et al. (2013) and Burukutu (pH 3.94) by Eze et al. (2011) and sorghum safari (Tchapalo) (pH 3.5 to 4.5 ) by Coulibaly et al. (2020), all produced in Cameroon, Ivory Coast, Burkina-Faso, Nigeria and Ghana, respectively, our investigated beers had similar values. Also, it showed that all our local beers had similar $\mathrm{pH}$ values both in the morning and in the evening, which is in accordance with those reported by Maoura et al. (2006) in Chad, where the $\mathrm{pH}$ value of Bil-Bil had not changed during the alcoholic fermented process. However, the results revealed that all the sample beers had an acidic $\mathrm{pH}$ range which can explain that an acidic medium is one of the main condition factors for developing yeast without any modification of $\mathrm{pH}$ (Maoura et al. 2006). The $\mathrm{pH}$ values of our local beers were within the desired parameters, generally between 3.8 and 4.7 , protecting the product against pathogens, as Suzuki et al. (2006) reported. The difference in $\mathrm{pH}$ value may be attributed to the processing methods, quality of raw material, and measure or quantification (Coulibaly et al. 2011). All pH values of our different local beers produced in Maroua town are within the value of CODEX (2005), which reported that beer with a $\mathrm{pH}$ lower than 4.5 could be the good quality for the consumers.

The titratable acid of the local beers also varied significantly among samples $(\mathrm{p}<0.05)$ (Table 2). Bil-Bil had the highest value $(4.89-6.25 \mathrm{mg} / \mathrm{mL})$. However, Frudu had a value of $3.04-4.58 \mathrm{mg} / \mathrm{mL}$, while Cochette had the lowest value $(2.31-3.40 \mathrm{mg} / \mathrm{mL})$. The values of titratable acid found in Bil-Bil beer are lower than the value $(0.06 \mathrm{mg} / \mathrm{mL})$ reported by Coulibaly et al. (2020) in sorghum safari (Tchapalo). Similarly, these values are lower than those Ourega et al. (2015) reported. They found that plantain beer had a titratable acid content ranging from 
0.08 to $0.9 .3 \mathrm{mg} / \mathrm{mL}$, suggesting that the raw material influenced the beers.

For the alcohol content, results summarized in Table 2 revealed that the alcohol value varied significantly among beers $(\mathrm{P}<0.05)$. The content of the Frudu beer sample varied between 5.40 and $6.92 \%$, while it folds from 1.08 to $5.10 \%$ for Cochette and between 1.73 and $2.88 \%$ for BilBil. The frudu beer had an alcoholic value higher than Cochette and Bil-Bil suggesting strong flavor and aroma compounds (Einfalt 2021). However, the alcohol content in Bil-Bil beer was significantly higher than the value reported by Muyanja et al. (2010) on Pito (3.09 \%) but lower than Tchapalo $(5.22 \%)$ processing with sorghum in Kenya, Nigeria, and Ivory Coast, respectively. The rice and white millet used for the processing of Furdu $(6.16 \%)$ and Cochette $(3.09 \%)$ had higher alcohol content than BilBil (Table 2). These differences in alcohol contents are due to the types or quality of yeasts used to ferment. These are consistent with the results of Einfalt (2021), who found that the alcohol content varied significantly with the type of yeast used for beer fermentation. However, the alcohol levels obtained in our different beers are obviously within the range of the French legal classification of types of beers ranging from table beer to special beer brochures of brewers of France (Hencké 2000).

The reducing sugar content of Furdu varied between 11.85 and $19.05 \mathrm{mg} / \mathrm{mL}$, while it folded from 2.20 to 9.46 $\mathrm{mg} / \mathrm{mL}$ for Cochette and 9.92 to $19.78 \mathrm{mg} / \mathrm{mL}$ for Bil-Bil (Table 3). The present results showed that Bil-Bil beers had a higher content of reducing sugars than Tchapalo $(0.4$ $\mathrm{mg} / \mathrm{mL}$ ) from the Ivory Coast (Amane et al. 2005). This difference may be due to the reducing sugar content of sorghum used to process the local beers. Also, the contents of total carbohydrates varied among these beers (Table 3). The carbohydrate content in Furdu beer folds from 16.05 to $46.35 \mathrm{mg} / \mathrm{mL}$, while in Cochette beer, it varies between
$15.39 \mathrm{mg} / \mathrm{mL}$ and $42.53 \mathrm{mg} / \mathrm{mL}$, and Bil-Bil, the values vary from 12.12 to $168.53 \mathrm{mg} / \mathrm{mL}$. It revealed that Bil-bil beer had a lower and higher value of carbohydrates than that obtained in Furdu and Cochette, respectively. Cortacero-Ramírez et al. (2003) stated that beer should contain between 3.3 to $4.4 \mathrm{~g} / 100$ carbohydrates. However, the value is higher than that reported by Chevassus-Agnes et al. (1976) in Ambga and Affouk beers (19 mg/mL) consumed in the North region of Cameroon. The differences in carbohydrate values are linked to the variety of cereals and their technologies used for processing.

The values of soluble amino acids and total soluble proteins were not found to vary significantly $(p>0.05)$ among the samples (Table 3). The soluble amino acids amount of the local beers were followed; Furdu had 3.40 to $7.37 \mathrm{mg} / \mathrm{mL}$, Cochette contained 3.98 to $6.01 \mathrm{mg} / \mathrm{mL}$, while Bil-Bil had 2.95 to $3.24 \mathrm{mg} / \mathrm{mL}$. However, Furdu beer had the highest amino acid contents than Cochette and Bil-Bil. Considering the total proteins, local beers had high values ranging from 0.80 to $0.85 \mathrm{mg} / \mathrm{mL}$, which was higher than those obtained in Kaffir beer $(0.05$ $\mathrm{mg} / \mathrm{mL}$ ) (Busson et al. 1970), in Amgba (0.07 mg/mL) (Chevassus-Agnes et al. 1976) (Table 3). For Ferreira and Guido (2018), the contents of soluble amino acids determine the quality of beer, suggesting the good quality of our sample beer analyzed.

The alcohol contents of distillate fractions from the morning and evening samples showed that the alcohol contents varied significantly $(\mathrm{p}<0.05)$ among different samples of beers named $\mathrm{FHoE}, \mathrm{FPvE}, \mathrm{CPiE}, \mathrm{BPvE}$, and $\mathrm{BPaE}$, however, there is no significant difference among FHoM, FPvM, CPvM, CPiM, BiPvM and BPiE (Figure 6). The values of alcohol content revealed that the first fraction (F1) of the distillate had higher alcohol content than the second fraction (F2) (Figure 6).

Table 2. Total dissolved solids (TDS), pH, dry matter, titratable acid (TA), and alcohol contents of local beers (Furdu, Cochette, Bil-Bil) were collected in the morning and evening from various streets in Maroua town.

\begin{tabular}{|c|c|c|c|c|c|}
\hline Sample & TDS (ppm) & pH & $\begin{array}{l}\text { Dry matter } \\
(\mathrm{g} / \mathbf{1 0 0 g})\end{array}$ & $\begin{array}{l}\text { T A } \\
(\mathrm{mg} / \mathrm{mL})\end{array}$ & $\begin{array}{l}\begin{array}{l}\text { Alcohol contents } \\
(\mathrm{g} / 100 \mathrm{~mL})\end{array} \\
\end{array}$ \\
\hline FHoM & $1771 \pm 70^{b}$ & $4.06 \pm 0.03^{c}$ & $6.96 \pm 0.22^{b}$ & $3.04 \pm 0.19^{\mathrm{i}}$ & $5.38 \pm 0.13^{b}$ \\
\hline FHoE & $1688 \pm 23^{c}$ & $4.06 \pm 0.04^{c}$ & $2.83 \pm 0.08^{\mathrm{h}}$ & $3.80 \pm 0.06^{\mathrm{g}}$ & $6.92 \pm 0.28^{\mathrm{a}}$ \\
\hline FPvM & $1939 \pm 28^{a}$ & $4.04 \pm 0.02^{\mathrm{d}}$ & $6.96 \pm 0.22^{b}$ & $4.58 \pm 0.32^{\mathrm{e}}$ & $5.47 \pm 0.26^{\mathrm{b}}$ \\
\hline FPvE & $1978 \pm 20^{\mathrm{a}}$ & $4.22 \pm 0.03^{\mathrm{a}}$ & $6.61 \pm 0.32^{b c}$ & $4.21 \pm 0.06^{\mathrm{f}}$ & $5.40 \pm 0.15^{\mathrm{b}}$ \\
\hline CPvM & $1409 \pm 26^{\mathrm{f}}$ & $4.15 \pm 0.02^{b}$ & $8.06 \pm 0.08^{a}$ & $2.63 \pm 0.13^{\mathrm{j}}$ & $1.08 \pm 0.23^{\mathrm{h}}$ \\
\hline $\mathrm{CPvE}$ & $1310 \pm 33^{\mathrm{g}}$ & $4.13 \pm 0.06^{b c}$ & $5.84 \pm 0.08^{\mathrm{e}}$ & $3.40 \pm 0.06^{\mathrm{h}}$ & $4.71 \pm 0.21^{\mathrm{cd}}$ \\
\hline CPiM & $625 \pm 34^{\mathrm{h}}$ & $3.84 \pm 0.03^{\mathrm{e}}$ & $6.09 \pm 0.24^{\mathrm{d}}$ & $2.72 \pm 0.13^{\mathrm{j}}$ & $4.31 \pm 0.31^{\mathrm{d}}$ \\
\hline $\mathrm{CPiE}$ & $513 \pm 28^{i}$ & $3.80 \pm 0.03^{\mathrm{e}}$ & $5.17 \pm 0.89^{f}$ & $2.31 \pm 0.06^{\mathrm{k}}$ & $5.10 \pm 0.25^{\mathrm{c}}$ \\
\hline BPiM & $1442 \pm 18^{e}$ & $3.46 \pm 0.02^{\mathrm{g}}$ & $6.98 \pm 0.37^{b}$ & $5.07 \pm 0.26^{\mathrm{d}}$ & $2.55 \pm 0.25^{\mathrm{f}}$ \\
\hline BPiE & $1434 \pm 11^{\mathrm{ef}}$ & $3.45 \pm 0.05^{\mathrm{g}}$ & $5.42 \pm 0.44^{\mathrm{ef}}$ & $5.84 \pm 0.32^{\mathrm{bc}}$ & $2.90 \pm 0.23^{\mathrm{e}}$ \\
\hline $\mathrm{BPaM}$ & $1495 \pm 24^{\mathrm{d}}$ & $3.44 \pm 0.02^{\mathrm{g}}$ & $4.88 \pm 0.10^{\mathrm{f}}$ & $4.89 \pm 0.26^{\mathrm{de}}$ & $1.73 \pm 0.13^{\mathrm{g}}$ \\
\hline $\mathrm{BPaE}$ & $1647 \pm 29^{c}$ & $3.53 \pm 0.03^{\mathrm{f}}$ & $6.31 \pm 0.07^{c}$ & $5.66 \pm 0.06^{c}$ & $1.82 \pm 0.26^{\mathrm{g}}$ \\
\hline BPiM & $1483 \pm 34^{\mathrm{de}}$ & $3.42 \pm 0.04^{\mathrm{gh}}$ & $4.24 \pm 0.09^{g}$ & $6.25 \pm 0.13^{\mathrm{a}}$ & $1.92 \pm 0.13^{\mathrm{g}}$ \\
\hline BPiE & $1441 \pm 11^{\mathrm{ef}}$ & $3.37 \pm 0.02^{\mathrm{h}}$ & $5.95 \pm 0.38^{\mathrm{de}}$ & $5.93 \pm 0.06^{\mathrm{b}}$ & $2.88 \pm 0.21^{\mathrm{ef}}$ \\
\hline
\end{tabular}

Values are means \pm standard deviation of three replicates $(n=3)$. In the same column, values followed by different superscript letters are significantly different ( $<$ 0.05). Note: FHo: Furdu beer collected in Ouro tchédé street; FPv: Furdu beer collected in Pont vert street; CPv: Cochette beer collected in Pont vert street; CPi: Cochette beer collected in Pitoaré street; BPv: Bil-Bil beer collected in Pont vert street; BPa: Bil-Bil beer collected in Palar street; BPi: Bil-Bil beer collected in Pitoaré street. Those beers were collected in the morning (M) or evening (E). 
Table 3: Reducing sugars, total amino acids, total carbohydrates, and total proteins of local beers (Furdu, Cochette, Bil-Bil) collected in the morning and evening from various streets in Maroua town. The values are expressed in $\mathrm{mg} / \mathrm{mL}$ of sample.

\begin{tabular}{lcccc}
\hline Sample & Reducing sugars & Carbohydrates & Total protein & Amino acids \\
\hline FHoM & $16.35 \pm 0.45^{\mathrm{d}}$ & $16.05 \pm 0.27^{\mathrm{h}}$ & $0.80 \pm 0.05^{\mathrm{b}}$ & $4.29 \pm 0.19^{\mathrm{c}}$ \\
FHoE & $17.33 \pm 0.63^{\mathrm{c}}$ & $37.75 \pm 0.99^{\mathrm{d}}$ & $0.83 \pm 0.03^{\mathrm{ab}}$ & $3.40 \pm 0.13^{\mathrm{e}}$ \\
FPvM & $11.85 \pm 1.02^{\mathrm{f}}$ & $46.35 \pm 1.14^{\mathrm{b}}$ & $0.84 \pm 0.02^{\mathrm{a}}$ & $6.00 \pm 0.16^{\mathrm{a}}$ \\
$\mathrm{FPvE}$ & $19.05 \pm 0.63^{\mathrm{a}}$ & $44.71 \pm 1.50^{\mathrm{bc}}$ & $0.83 \pm 0.02^{\mathrm{ab}}$ & $7.37 \pm 0.15^{\mathrm{a}}$ \\
$\mathrm{CPvM}$ & $8.30 \pm 0.54^{\mathrm{h}}$ & $35.97 \pm 1.17^{\mathrm{d}}$ & $0.83 \pm 0.06^{\mathrm{ab}}$ & $5.83 \pm 0.17^{\mathrm{b}}$ \\
CPvE & $9.46 \pm 0.37^{\mathrm{gh}}$ & $42.53 \pm 0.63^{\mathrm{c}}$ & $0.84 \pm 0.05^{\mathrm{a}}$ & $3.98 \pm 0.15^{\mathrm{d}}$ \\
$\mathrm{CPiM}$ & $2.20 \pm 0.58^{\mathrm{j}}$ & $28.34 \pm 0.89^{\mathrm{e}}$ & $0.83 \pm 0.04^{\mathrm{ab}}$ & $6.01 \pm 0.07^{\mathrm{b}}$ \\
$\mathrm{CPiE}$ & $5.56 \pm 0.22^{\mathrm{i}}$ & $15.39 \pm 0.55^{\mathrm{h}}$ & $0.83 \pm 0.04^{\mathrm{ab}}$ & $4.44 \pm 0.09^{\mathrm{c}}$ \\
$\mathrm{BPvM}$ & $13.06 \pm 0.65^{\mathrm{e}}$ & $19.00 \pm 0.80^{\mathrm{g}}$ & $0.81 \pm 0.02^{\mathrm{b}}$ & $3.15 \pm 0.17^{\mathrm{f}}$ \\
$\mathrm{BPvE}$ & $9.92 \pm 0.41^{\mathrm{g}}$ & $12.12 \pm 0.69^{\mathrm{i}}$ & $0.81 \pm 0.02^{\mathrm{b}}$ & $3.03 \pm 0.13^{\mathrm{gf}}$ \\
$\mathrm{BPaM}$ & $17.51 \pm 0.84^{\mathrm{bc}}$ & $18.81 \pm 0.43^{\mathrm{g}}$ & $0.83 \pm 0.04^{\mathrm{ab}}$ & $3.02 \pm 0.16^{\mathrm{gf}}$ \\
$\mathrm{BPaE}$ & $16.32 \pm 0.71^{\mathrm{d}}$ & $168.53 \pm 1.52^{\mathrm{a}}$ & $0.83 \pm 0.02^{\mathrm{ab}}$ & $3.01 \pm 0.04^{\mathrm{g}}$ \\
BPiM & $18.02 \pm 0.48^{\mathrm{b}}$ & $24.49 \pm 0.79^{\mathrm{f}}$ & $0.85 \pm 0.03^{\mathrm{a}}$ & $2.95 \pm 0.08^{\mathrm{g}}$ \\
\hline Val & $19.78 \pm 0.58^{\mathrm{a}}$ & $27.80 \pm 1.04^{\mathrm{e}}$ & $0.80 \pm 0.02^{\mathrm{b}}$ & $3.24 \pm 0.10^{\mathrm{ef}}$ \\
\hline
\end{tabular}

Values are means \pm standard deviation of three replicates $(n=3)$. In the same column, values followed by different superscript letters are significantly different ( $<$ 0.05). Note: FHo: Furdu beer collected in Ouro tchédé street; FPv: Furdu beer collected in Pont vert street; CPv: Cochette beer collected in Pont vert street; CPi: Cochette beer collected in Pitoaré street; BPv: Bil-Bil beer collected in Pont vert street; BPa: Bil-Bil beer collected in Palar street; BPi: Bil-Bil beer collected in Pitoaré street. Those beers were collected in the morning (M) or evening (E).

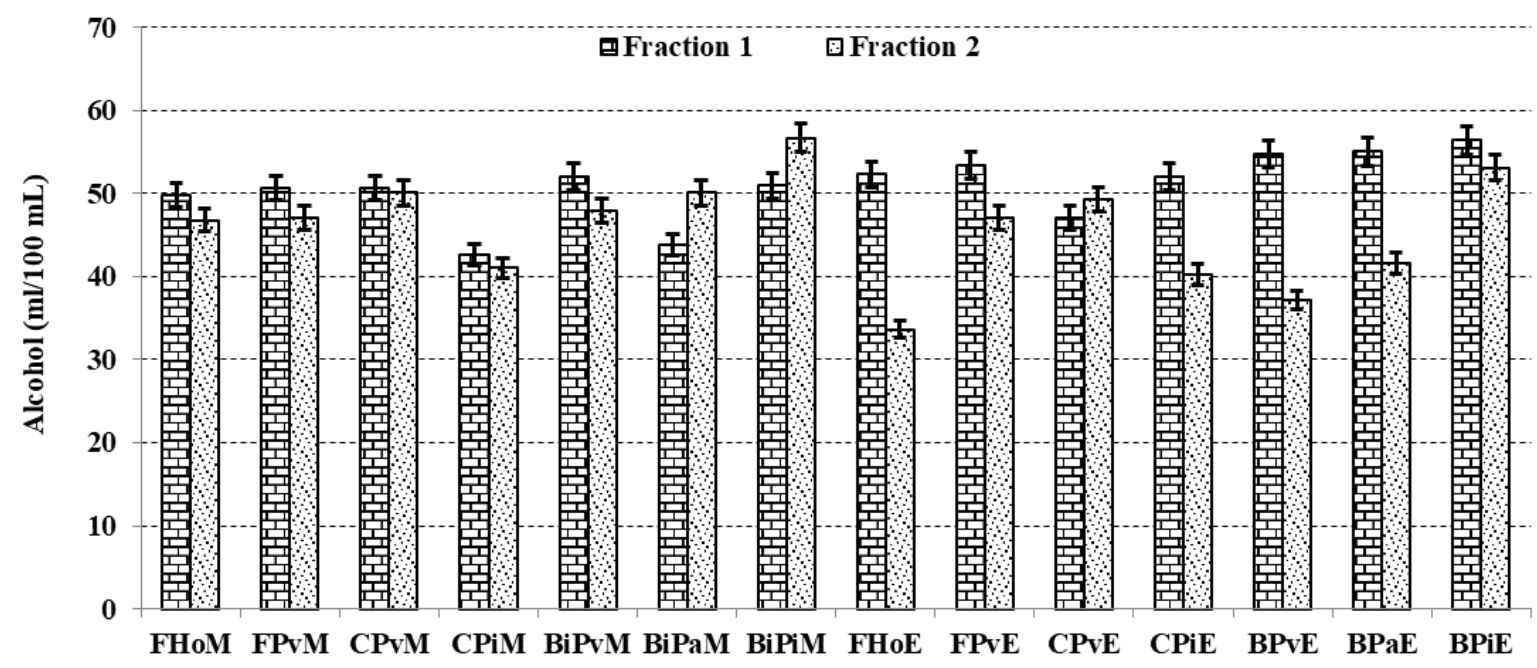

Figure 5. Alcohol contents (mL/100 mL) of distillate obtained from local beers (Furdu, Cochette, Bil-Bil) were collected in the morning and evening from several streets in Maroua town, Cameroon. Note: FHo: Furdu beer collected in Ouro tchédé street; FPv: Furdu beer collected in Pont vert street; CPv: Cochette beer collected in Pont vert street; CPi: Cochette beer collected in Pitoaré street; BPv: Bil-Bil beer collected in Pont vert street; BPa: Bil-Bil beer collected in Palar street; BPi: Bil-Bil beer collected in Pitoaré street. Those beers were collected in the morning $(\mathrm{M})$ or evening $(\mathrm{E})$.

This result may be because at the start of the distillation; a strong alcohol type has been collected with a very strong odor with a sour taste and a characteristic aroma, which relatively increased the alcohol content (Aka et al. 2008). On the other hand, at the end of the distillation, we observed an increase in temperature and, consequently, an alteration of the distillate and other volatile compounds, which decreased the alcohol content by water interference. In general, ethanol was the main constituent of distillates. However, this does not characterize the quality of the distillates. As indicated by Huot and Roy (1999), other flavors from many organic substances, such as esters, aldehydes, and other alcoholic compounds, must also interfere with the alcoholic degree of the distillates. These compounds may influence the quantity and quality of distilled ethanol. An ethyl acetate that had also been found in cassava spirits indicated that the distilled beverages such as whiskey, rum, and Cachaça affected their quality (Coelho et al. 2020).

At less significant values, samples of distillates collected in the evening are richer in alcohol than those obtained in the morning, suggesting that this fraction was rich in flavor compounds. Fact, the principal high alcohol in alcoholic beverages include 1-propanol, 2-methyl-1- 
propanol (isobutanol), 3-methyl-1-butanol (isoamylol), and 2-phenylethanol (Zhou et al., 2020). Likewise, some samples saw their second fraction more concentrated than the first one (Figure 6). This difference could be due especially to the yeast inoculation time (Einfalt 2021) and the fermentation time because some local beers have not reached their fermentation or maturation threshold early in the morning, which can affect the quality of the distillate. In fact, the fermentation process develops with an increase in the alcohol level (Périsse et al. 1959).

In conclusion, the aim of this present study was to investigate the physicochemical characteristics of various local beers produced and consumed in Maroua town, as well as the types of cereals used to produce these craft beers. Various cereals (red sorghum, white sorghum, maize, yellow millet, S35, rice, fonio, etc.) are mainly used to process different local beers. The volume of distillate increased over time and depended on one beer to another. The sample of BPiM and CPiM had the lowest and the highest temperature values during distillation, respectively. Furdu beer had the highest TDS value (1688-1978 ppm), $\mathrm{pH}$ value (4.06-4.22), and high level of alcohol (5.40-6.92 $\%)$. However, Cochette had the highest level of dry matter (5.17-8.06\%). Bil-Bil had the highest titratable acid value (4.89 mg/mL-6.25 mg/mL). The distillate of the local beers had high alcohol levels and varied from one beer to another and one fraction to another, with the values varying between 30 and $58.03 \%$. These results revealed that various cereals would be suitable as raw materials for producing quality beers such as white beers, beers, and spirits and provide a basis to foster the production of value-added products from these cereals. This study shows that the local beers are rich in nutriment and could offer a greater source of benefit to consumers.

\section{REFERENCES}

Abdoul-Latif FM, Bassolé IH, Dicko MH. 2013. Proximate composition of traditional local sorghum beer "dolo" manufactured in Ouagadougou. Afr J Biotechnol 12(13) : 1517-1522.

Aka S, Djeni NT, N'guessan KF, Yao KC, Dje KM. 2008. Variabilité des propriétés physico-chimiques et dénombrement de la flore fermentaire du tchapalo, une bière traditionnelle de sorgho en Côte d'Ivoire. Afr Sci 04 : 2274-286. DOI: 10.4314/afsci.v4i2.61688.

Amane ND, Assidjo NE, Gbongue MA, Bohoussou K, Cardot P. 2006 Caractérisation physico-chimique d'une bière traditionnelle ouest Africaine: Le Tchapalo bière traditionnelle tchadienne. Agron Afr 17 (2) : 143-152. DOI: 10.4314/aga.v17i2.1665

Anderson NG. 2012. Practical Process Research and Development A guide for Organic Chemists. 2nd ed. Springer, New York.

AOAC. 2000. Official Methods of Analysis of the Association of Official Analytical Chemists International 17th Ed. Published by the Association of Official Analytical Chemists International, Suite 400 2200 Wilson Boulevard, Arlington, Virginia, USA.

Ascher B. 2012. Global beer-the road to monopoly. Am Antitrust Instit, Washington.

Attchelouwa CK, N'guessan FK, Marcotte S, Amoikon TL, Charmel M, Dje MK. 2020. Characterisation of volatile compounds associated to sensory changes during the storage of traditional sorghum beer by HS-GC/FID and SPME-GC/MS. J Agric Food Res DOI: 10.1016/j.jafr.2020.100088

Bamforth CW. 2002. Nutritional aspects of beer-a review. Nutr Res 22 227-237. DOI : 10.1016/S0271-5317(01)00360-8

Bradford MM. 1976. A rapid and sensitive Method for the Quantification of microgram quantities of protein utilizing the principe of protein- due binding. Anal Biochem 72: 248-254. DOI: 10.1006/abio.1976.9999

Busson F, Jardin C, Wu Leung WT. 1970. Table de composition des aliments à l'usage de l'Afrique.

Caputi A, Ueda M, Brown T. 1968. Spectrophotometric determination of ethanol in wine. Am J Enol Vitic 68 (2): 188-90.

Charles T, Jong NE, Robert N. 2018. Production du Bili-Bili, bière traditionnelle de sorgho du Nord Cameroun: Diversité des procédés de production et qualité des produits. Eur Sci J 14 (36): 207-224. DOI: 10.19044/esj. v14n36p207

Chevassus-Agnes JC, Favier, Joseph A. 1976. Traditional technology and the nutritive value of sorghum beer from Cameroon. Cahiers de Nutrition et de Dietetique (France).

Ciriminna R, Albanese L, Di Stefano V, Delisi R, Avellone G, Meneguzzo F, Pagliaro M. 2018. Beer produced via hydrodynamic cavitation retains higher amounts of xanthohumol and other hops prenylflavonoids. Lebensmittel-Wissenschaft und. Lwt 91 : 160-167. DOI : $10.1016 / \mathrm{j}$. lwt.2018.01.037

CODEX Stan 247. 2005. In "Norme générale codex pour les jus et les nectars de fruits".

Coelho E, Ballesteros LF, Domingues L, Vilanova M, Teixeira JA. 2020. Production of a distilled spirit using cassava flour as raw material: chemical characterization and sensory profile. Molecules 25 (14): 3228. DOI: 10.3390/molecules25143228.

Cortacero-Ramírez S, Hernáinz-Bermúdez de Castro M, Segura-Carretero A, Cruces-Blanco C, Fernández-Gutiérrez A. 2003. Analysis of beer components by capillary electrophoresis methods. Trends Anal Chem 22 (7) : 440-445. DOI : 10.1016/S0165-9936(03)00704-0.

Coulibaly WH, Bouatenin KM, Boli ZB, Alfred KK, Bi YC, N'sa KM, Cot M, Djameh C, Djè KM. 2020. Influence of yeasts on bioactive compounds content of traditional sorghum beer (tchapalo) produced in Côte d'Ivoire. Cur Res Food Sci 3: 195-200. DOI : 10.1016/j.crfs.2020.06.001

Djanan D, Mbayhoudel K, Nandoum M. 2002. Organisation des unités de transformation artisanale en zone de savanes: Cas de la transformation du sorgho en bière locale bili-bili à Moundou au Tchad. In Savanes africaines: des espaces en mutation, des acteurs face à de nouveaux défis. Actes du colloque, Garoua, Cameroun. Cirad-Prasac.

Dubois M, Gilles KA, Hamilton JK, Rebers PA, Smith F. 1956. Colorimetric method for determination of sugars and related substances. Anal Chem 28: 350-356. DOI: 10.1021/ac60111a017.

Einfalt D. 2021. Barley-sorghum craft beer production with Saccharomyces cerevisiae, Torulaspora delbrueckii and Metschnikowia pulcherrima yeast strains. Eur Food Res Technol 247: 385-393 DOI : 10.1007/s00217-020-03632-7.

Eze VC, Eleke OI, Omeh YS. 2011. Microbiological and nutritional qualities of burukutu sold in mammy market Abakpa, Enugu State, Nigeria. Am J Food Nutr 1 (3): 141-146. DOI: 10.5251/ajfn.2011.1.3.141.146

Fadahunsi IF, Ogunbanwo ST, Fawole AO. 2013. Microbiological and nutritional assessment of burukutu and pito (indigenously fermented alcoholic beverages in West Africa) during storage. Nat Sci 11 (4): 98-103.

Ferreira IM, Guido LF. 2018. Impact of wort amino acids on beer flavour: A review. Fermentation 4 (2): 23. DOI: 10.3390/fermentation402003

Gómez-Corona C, Escalona-Buendía HB, García M, Cholle S, Valentin D. 2016. Craft vs. industrial: Habits, attitudes and motivations towards beer consumption in Mexico. Appetite 96: 358-367. DOI : 10.1016/j.appet.2015.10.002. PMid:26455311

Hazelwood LA, Daran JM, Van Maris AJA, Pronk JT, Dickinson JR. 2008. The Ehrlich pathway for fusel alcohol production: A century of research on Saccharomyces cerevisiae metabolism. Appl Environ Microbiol 74: 2259-2266. DOI : 10.1128/AEM.02625-07

Hencké S. 2002. Utilisation alimentaire de levure, thèse de Doctorat en pharmacie Université Henri Poincae-Nancy I.

Humia BV, Santos K, Barbosa A, Sawata M, Mendonca M, Padilha F. 2019. Beer molecules and its sensory and biological properties. Molecules 24 (8) : 1568. DOI : 10.3390/molecules24081568

Huot R, Roy GY. 1999. Livre De Chimie Organique Notions Fondamentales, Ed Carcajou 325-338.

Kayodé APP, Adégbidi A, Linnemann AR, Nout MJR, Hounhouigan DJ. 2005. Quality of farmer's varieties of sorghum and derived foods as perceived by consumers in Benin. Ecol Food Nutri 44 (4): 271-294. DOI : $0.1080 / 03670240500187302$ 
Lariven J, Sonia R. 2017. Brasseurs de France la bière dossier de Presse. $2-19$

Lyumugabe F, Kamaliza G, Bajyana E, Thonart PH. 2010. Microbiological and physico-chemical characteristic of Rwandese traditional beer "Ikigage". Afr J Biotechnol 9 (27): 4241-4246.

Maoura N, Gaillardin MC, Jacques. 2006. Pourquie Suivi technique, Analytique et Microbiologique de la « bili bili », Bière traditionnelle Tchadienne. Afr J Biotechnol 2 (1): 69-82. DOI: 10.4314/afsci.v2i1.61135

Michel MC, Hannequart G. 1968. Dosage des acides amines et amine par la ninhynidrine. Amélioration pratique. In Ann Biol Anim Biochim Biophysique 8 (4): 557-563. DOI: 10.1051/rnd:19680408

Miller GL. 1972. Use of Dinitosalicylic Acid Reagent for determination of reducing sugars. Anal Chem 31: 426-428. DOI: 10.1021/ac60147a030

Muyanja CMBK, Narvhus JA, Treimo J, Langsrud T. 2003. Isolation, characterisation and identification of lactic acid bacteria from bushera: A Ugandan traditional fermented beverage. Int J Food Microbiol 80 (3): 201-210. DOI : 10.1016/S0168-1605(02)00148-4

N'da Coulibaly S. 1996. Etude comparative de procédés traditionnels de préparation d'une bière locale appelée tchapalo. 2ème journées annuelles de la SOACHIM, Dakar-Sénégal.

Nascimento ESP, Cardoso DR, Franco DW. 2008. Quantitative ester analysis in Cachaça and distilled spirits by Gas ChromatographyMass Spectrometry (GC-MS). J Agric Food Chem 56 (14): 54885493. DOI: $10.1021 /$ jf800551d

Odunfa SA. 1985. African Fermented Foods. Microbiol Fermented Foods 2: 155-191. DOI: 10.1080/0142968X.1985.11904309
Olaniran AO, Hiralal L, Mokoena M P, Pillay N. 2017. Flavour-active volatile compounds in beer: Production, regulation and control. J Inst Brew 123 (1): 13-23. DOI : 10.1002/jib.389.

Ourega L, Ban K, Kouadio FN, Guessan G, Nemlin J, Tano K. 2015. Physico-chemical characteristics of plantain beers produced from waste plantain varieties of Côte d'Ivoire (Orishele, French Horn 2 and 1). Int J Innov Appl Stud 10 (2): 666-677.

Perisse J, Adrian J, Rerat A, Le Berre S. 1959. Nutrient balance in the transformation of sorghum into beer. Preparation, composition and consumption of a Togo beer. In Annales de la Nutrition et de l'Alimentation 13: 1-15.

Ranganna S. 1979. Titratable acidity. Manual of analysis of fruit and vegetable products.

Roger DD, Venassius L, Justin EN, Franccedil E. 2013. Processing of Amgba: A sorghum-maize based beer, brewed in Cameroon. J Brew Distilling 4 (1): 11-18. DOI: 10.5897/JBD12.004

Setta MC, Matemu A, Mbega ER. 2020. Potential of probiotics from fermented cereal-based beverages in improving health of poor people in Africa. J Food Sci Technol 57 (11): 3935-3946. DOI: 10.1007/s13197-020-04432-3.

Suzuki K, Iijima K, Sakamoto K, Sami M, Yamashita H. 2006. A review of hop resistance in beer spoilage lactic acid bacteria. J Inst Brew 112 (2): 173-191. DOI : 10.1002/j.2050-0416.2006.tb00247.x

Zhou Z, Ni W, Ji Z, Liu S, Han X, Li X, Mao J. 2020. Development of a rapid method for determination of main higher alcohols in fermented alcoholic beverages based on dispersive liquid-liquid microextraction and gas chromatography-mass spectrometry. Food Anal Methods 13: 591-600. DOI: 10.1007/s12161-019-01668-4 